\title{
Potato virus Y: Contact Transmission, Stability, Inactivation, and Infection Sources
}

B. A. Coutts and R. A. C. Jones, Crop Protection Branch, Department of Agriculture and Food Western Australia, Locked Bag No. 4, Bentley Delivery Centre, Perth, WA 6983, Australia, and School of Plant Biology and Institute of Agriculture, Faculty of Science, University of Western Australia, 35 Stirling Highway, Crawley, WA 6009, Australia

\begin{abstract}
Coutts, B. A., and Jones, R. A. C. 2015. Potato virus Y: Contact transmission, stability, inactivation, and infection sources. Plant Dis. 99:387-394.

In glasshouse experiments, two isolates of Potato virus $Y$ ' $\mathrm{O}$ ' strain $\left(\mathrm{PVY}^{\mathrm{O}}\right)$ were transmitted from infected to healthy potato plants by direct contact when leaves were rubbed against each other, when cut surfaces of infected tubers were rubbed onto leaves, and to a limited extent, when blades contaminated with infective sap were used to cut healthy potato tubers. However, no tuber-to-tuber transmission occurred when blades were used to cut healthy tubers after cutting infected tubers. When leaf sap from potato plants infected with two $\mathrm{PVY}^{\mathrm{O}}$ isolates was kept at room temperature, it was highly infective for 6 to $7 \mathrm{~h}$ and remained infectious for up to $28 \mathrm{~h}$. Also, when sap from infected leaves with one isolate was applied to five surfaces (cotton, hessian, metal, rubber vehicle tire, and wood) and left to dry for up to $24 \mathrm{~h}$ before each surface was rubbed onto healthy tobacco plants, PVYO remained infective for $24 \mathrm{~h}$ on tire and metal, $6 \mathrm{~h}$ on cotton and hessian, and $3 \mathrm{~h}$ on wood. The effectiveness of disinfectants at inactivating this isolate was evaluated by adding them to sap from infected

leaves which was then rubbed onto healthy tobacco plants. None of the plants became infected when bleach (42 g/liter sodium hypochlorite, diluted 1:4) or Virkon-S (potassium peroxymonosulfate $50 \% \mathrm{wt} / \mathrm{wt}$, diluted to $1 \%$ ) was used. A trace of infection remained after using nonfat milk powder $(20 \% \mathrm{wt} / \mathrm{vol})$. PVY infection sources were studied in $2011-$ 2012 in the main potato growing regions of southwest Australia. In tests on $>17,000$ potato leaf samples, PVY was detected at low levels in seed $(4 / 155)$ and ware (6/51) crops. It was also detected in volunteer potatoes from a site with a previous history of PVY infection in a seed crop. None of the 15 weed species tested were PVY infected. Plants of Solanum nigrum were symptomlessly infected with $\mathrm{PVY}^{\mathrm{O}}$ after sap inoculation, and no seed transmission was detected ( $>2,500$ seeds). This study demonstrates PVYO can be transmitted by contact and highlights the need to include removal of volunteer potatoes and other on-farm hygiene practices (decontaminating tools, machinery, clothing, etc.) in integrated disease management strategies for PVY in potato crops.
\end{abstract}

Potato virus Y (PVY; family Potyviridae, genus Potyvirus) has become the most economically important virus of potato crops worldwide. It is nonpersistently transmitted by a number of potato colonizing and noncolonizing aphid species $(17,28,30,49)$. It is tuber-borne, and has a wide range of naturally occurring hosts mainly in the Solanaceae, including economically important crops (e.g., tomato, pepper, tobacco) and weeds such as Solanum nigrum (black nightshade) (30). In potato, PVY infection affects foliage and tubers, with symptom type and severity depending on PVY strain, potato cultivar, environmental conditions, and current season (primary) or tuber-borne (secondary) infection. When potato crops become infected by PVY, losses in crop yield and tuber quality often occur $(9,20,42,49,52)$. Control measures have been studied and integrated disease management approaches devised $(9,15,18,25,32,36,45,49)$. The most important control measure is planting seed tubers that are healthy or at least have minimal PVY infection (e.g., less than 1\% PVY incidence) $(9,48)$. Potato seed certification schemes which limit PVY incidences in planting material occur in many countries $(9,15,48,49)$.

PVY strain groups are distinguished biologically using inoculation to plants of potato differentials with resistance genes and tobacco, and phylogenetically. The two main biological groups commonly recognized are the ordinary $\left(\mathrm{PVY}^{\mathrm{O}}\right)$ and tobacco veinal necrosis $\left(\mathrm{PVY}^{\mathrm{N}}\right)$ strain groupings, but three other biological strain groups occur, $\mathrm{PVY}^{\mathrm{C}}, \mathrm{PVY}^{\mathrm{E}}$, and $\mathrm{PVY}^{\mathrm{Z}}(24,27,31,47)$. In the past 30 years, recombination between some of these strain groups as

Corresponding author: Brenda Coutts,

E-mail: brenda.coutts@agric.wa.gov.au

Accepted for publication 23 September 2015.

http://dx.doi.org/10.1094/PDIS-07-14-0674-RE

(C) 2015 The American Phytopathological Society well as mutation events have given rise to new strain groups defined by phylogeny rather than biologically, including PVY ${ }^{\mathrm{NTN}}$, $\mathrm{PVY}^{\mathrm{N}-\mathrm{Wi}}$, and PVY $\mathrm{Y}^{\mathrm{N}: \mathrm{O}}$. Moreover, as a consequence of this recombination, the composition of the PVY strain populations within potato growing areas in many parts of the world has changed greatly over time, including generation of variants that cause tuber necrosis in sensitive potato cultivars. However, the biological and phylogenetic strain grouping systems for PVY do not coincide in most cases $(18,25,27,29,40)$.

Typically, contact transmissible viruses have stable virus particles that achieve high concentrations within host cells. Such viruses include species in the genera Carlavirus (14), Potexvirus $(23,33,38)$ Sobemovirus (38), and Tobamovirus $(16,23)$. When spread of the lower concentration, less stable PVY was investigated in glasshouse-grown tomatoes, it was found to spread readily between plants on contaminated pruning tools (54). Moreover, another Potyvirus, Zucchini yellow mosaic virus (ZYMV), was found to be contact transmissible when infected cucurbit plants came in contact with healthy plants (7). In general publications on potato production and virus management, PVY has sometimes been reported to be spread by contact transmission during seed cutting, by contact between plants, on-farm equipment (machinery and tools), and when plants are damaged when people move through fields $(3,5,15,41)$. De Bokx $(8)$ reported that $\mathrm{PVY}^{\mathrm{N}}$ could be transmitted when handling sprouted tubers or when tubers were passed through brushing machines. Fletcher et al. (12) suggested that limited spread of PVY ${ }^{\mathrm{N}}$ in crops was due in part to seed hygiene measures that reduced contact transmission of the virus. Draper and Gudmestad (10) reported PVY transmission when cutting healthy tubers with hand-held cutting knives previously used to cut infected tubers. In contrast, Sturz et al. (50) found no evidence of tuber-to-tuber $\mathrm{PVY}^{\mathrm{O}}$ transmission in five potato cultivars by hand-held or mechanical cutting knives.

Infective sap of highly stable, contact transmissible viruses remains infective on different surfaces. For example, Potato virus $X$ 
(PVX, genus Potexvirus) remained infective for up to $3 \mathrm{~h}$ on metal and rubber surfaces, and up to $6 \mathrm{~h}$ on cotton fabric (55). Also, Tomato mosaic virus (TMV, genus Tobamovirus) remained infective for several weeks on various glasshouse surfaces and clothing (4). In addition, the less stable and lower concentration virus ZYMV remained infective for up to $6 \mathrm{~h}$ on cotton, rubber shoe sole, and metal surfaces, up to $24 \mathrm{~h}$ on plastic, and up to $48 \mathrm{~h}$ on tire (7). Disinfectants commonly found useful at inactivating viruses in infective sap include sodium hypochlorite and nonfat dry milk $(7,23,26,34,43)$.

Given the contradictory reports for PVY transmission in potato via plant-to-plant leaf contact and tuber-to-tuber by cutting $(10,50)$, contact transmissibility of PVY in potato warrants further investigation. In Australia, no research has been done on contact transmission of PVY, which was considered a minor cause of disease in potato until 2003 when PVY ${ }^{\mathrm{NTN}}$ was found associated with tuber ringspot necrotic symptoms in southeast Australia (44,56). Since that time, PVY has become the predominant virus problem in seed potato production in that region. PVY strains $\mathrm{PVY}^{\mathrm{O}}$ and $\mathrm{PVY}^{\mathrm{C}}$ were found in eastern Australia since the 1940s, and PVY ${ }^{\mathrm{N}}$ in the 1970s $(1,2,21)$. In southwest Australia, prior to 2003, surveys of potato crops and routine testing of certified seed schemes failed to detect PVY (22,53). However, by 2010-2011 PVY (in potato) and $\mathrm{PVY}^{\mathrm{C}}$ (in tomato) became established, but $\mathrm{PVY}^{\mathrm{O}}$ still occurs only rarely in seed and ware potato crops, and no other PVY strains have been found (29).

This paper describes a series of glasshouse experiments to establish (i) whether $\mathrm{PVY}^{\mathrm{O}}$ can be transmitted from infected to healthy potato plants by leaf or cut tuber rubbing; (ii) if $\mathrm{PVY}^{\mathrm{O}}$ can be transmitted to healthy tubers when cut with $\mathrm{PVY}^{\mathrm{O}}$ contaminated blades; (iii) the stability of PVY ${ }^{\mathrm{O}}$ in sap over time and when dried onto five surfaces; and (iv) the effectiveness of disinfectants in inactivating it in infective sap. It also establishes the occurrence of PVY infection sources in the main potato growing regions of southwest Australia (Fig. 1) and investigates its seed transmissibility in S. nigrum.

\section{Materials and Methods}

Plants, virus isolates, sap inoculation, and antiserum. All plants were grown in insect-proof, air-conditioned glasshouses

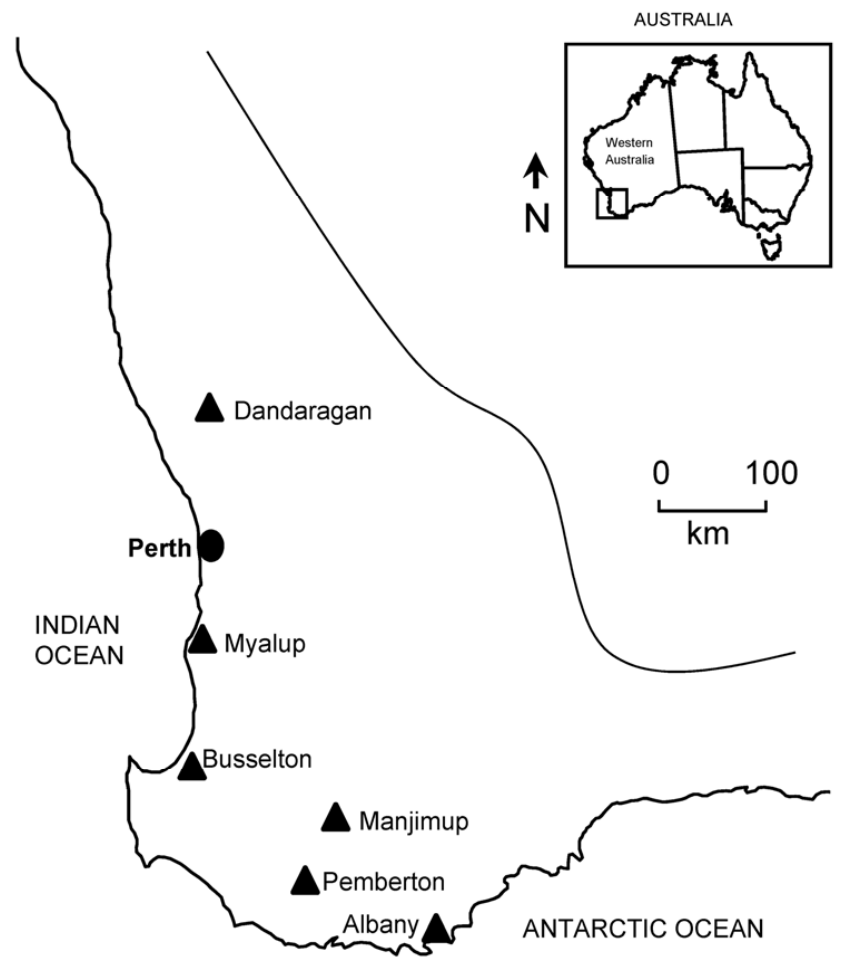

Fig. 1. Main potato growing regions in southwest Western Australia. maintained at 18 to $22^{\circ} \mathrm{C}$. Plants of potato (cvs. Atlantic, Bliss, Innovator, White Rose [aka Delaware in Australia $(11,35)$ ], and White Star) and tobacco (Nicotiana tabacum) cv. white burley were grown in pots in a steam-sterilized soil, sand, and peat mix (1:1:1). PVY ${ }^{\mathrm{O}}$ isolates Del-3 and BL were from previous studies (29). Both isolates were maintained in potato plants grown from infected tubers of cvs, White Rose and Bliss. These cultures were the sources of PVY inoculum for glasshouse experiments and used as the positive control in enzyme-linked immunosorbent assay (ELISA). For sap inoculation, infected leaves were ground

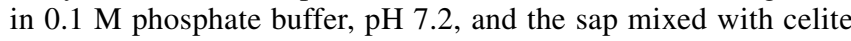
before being rubbed onto the leaves of plants. The polyclonal antisera to PVY, PVX, Potato leafroll virus (PLRV, genus Polerovirus), Potato virus S (PVS, genus Carlavirus), and Tomato spotted wilt virus (TSWV, genus Tospovirus) were from Loewe Biochemica, Germany. Positive controls for PLRV, PVX, and PVS were from potato plants grown from infected tubers. TSWV was from an isolate originating from tomato from southwest Australia and maintained by sap inoculation in tomato cv. Grosse Lisse. Tip leaf samples from all healthy potato plants used in glasshouse experiments were tested by ELISA for PVY presence before inoculation or for healthy tuber production to ensure they were virus-free.

ELISA. To test for virus infection, leaf samples were extracted singly in phosphate buffered saline $(10 \mathrm{mM}$ potassium phosphate, $150 \mathrm{mM}$ sodium chloride), $\mathrm{pH} 7.4$, containing $5 \mathrm{ml} /$ liter of Tween 20 and $20 \mathrm{~g} /$ liter of polyvinyl pyrrolidone, using a mixer mill (Retsch, Germany). Sample extracts were tested for PVY by double antibody sandwich ELISA (6). Each sample was tested in duplicate wells in microtiter plates, and appropriate infected and healthy leaf samples were included in duplicate wells as controls. The substrate used was $1.0 \mathrm{mg} / \mathrm{ml}$ of $p$-nitrophenyl phosphate in $100 \mathrm{ml} /$ liter of diethanolamine, $\mathrm{pH}$ 9.8. Absorbance values $\left(A_{405}\right)$ were measured in a microplate reader (Bio-Rad Laboratories). Positive absorbance values were always at least 10 times those of healthy sap.

Contact transmission. For the purpose of these experiments, contact transmission refers to when infected plant sap comes into contact with healthy plants in the absence of an abrasive and without causing visible damage.

Leaf-to-leaf contact. To investigate whether PVY could spread from infected to healthy plants by leaf-to-leaf contact, a potato leaf infected with PVY isolate Del-3 (three experiments) or BL (four experiments) was gently rubbed onto the upper leaf surface of a healthy potato plant such that no visual damage occurred. Healthy potato cultivars used were: Bliss and White Rose (one experiment with each isolate), Atlantic and White Star (one experiment each with isolate BL), and Innovator (one experiment with isolate Del3 ). Each experiment consisted of nine to 12 plants, and the upper leaf surfaces of three fully expanded leaves on each plant were rubbed with an infected leaf. Five plants were rubbed with healthy potato leaves as controls for each experiment. All plants were examined weekly for symptom development, and a single newly emerged leaf was sampled from each plant from 21 up to 48 days after rubbing and tested individually for PVY by ELISA.

Tuber-to-leaf contact. To determine whether PVY could spread from cut infected tubers, six experiments were done. The tubers used were removed from cold storage several days before cutting. Newly sprouting tubers infected with PVY isolates Del-3 (one experiment) or BL (five experiments) were cut in half with a scalpel with a blade (size 22), a new blade being used for each tuber. The cut tuber surface was immediately rubbed onto the upper leaf surface of healthy potato plants of cvs. Bliss (three experiments with isolate $\mathrm{BL}$ ) or White Rose (two experiments with isolate BL, one experiment with isolate Del-3) so that no visual damage occurred. Each experiment consisted of seven to 12 plants with the upper leaf surface of six leaves on each plant being rubbed with one half of the cut infected tuber. Six plants were left uninoculated as controls for each experiment. All plants were examined weekly for symptom development, and a single newly emerged leaf was 
sampled from each plant from 21 up to 40 days after rubbing and tested individually for PVY by ELISA. Each piece of cut infected tuber used to rub healthy plants was planted and tip leaf samples from the shoots tested for PVY by ELISA.

Leaf sap contaminated cutting blades to tubers. Eight experiments were done to determine if PVY could be spread from contaminated cutting blades to healthy tubers. All healthy tubers used were from plants grown in the glasshouse and tested by ELISA to ensure they were free from PVY infection before the tubers were harvested. A knife (blade length $10 \mathrm{~cm}$ ) was dipped into sap extracted from potato leaves infected with PVY isolate BL (three experiments) or Del-3 (five experiments) and then used to cut a healthy tuber in half. Healthy tubers (10 to 20 per experiment) of cvs. White Rose (two experiments each with BL and Del-3), Bliss (one experiment with BL, two experiments with Del-3), and White Star (one experiment with Del-3) were used. The knife was dipped into the PVY infective sap between each cut. The tuber pieces were left overnight at room temperature to heal and then planted in the glasshouse. All sprouted plants were examined for symptom development, and a single newly emerged leaf was sampled from each plant from 21 up to 62 days after planting and tested individually for PVY by ELISA.

Tuber-to-tuber cutting transmission. Four experiments were done to determine if PVY could be spread from infected tubers to healthy tubers via cutting blades. The tubers used were removed from cold storage one day before cutting. Newly sprouting tubers infected with PVY isolates Del-3 (two experiments) or BL (two experiments) were cut with a scalpel with a blade (size 22). The blade was immediately used to cut a healthy tuber in half (small tubers) or quarters (large tubers) of cvs. Bliss or White Rose (one experiment each with isolates BL and Del-3), a new blade being used for each tuber (10 to 40 tubers per experiment, total 100 tubers). The cut tuber pieces were left for $24 \mathrm{~h}$ at room temperature to heal and then planted. All sprouted plants were examined for symptom development, and a single newly emerged leaf was sampled from each plant from 28 up to 42 days after planting and tested individually for PVY by ELISA. Each piece of cut infected tuber was planted and tip leaf samples from the shoots tested for PVY by ELISA.

Stability. Survival in dried sap. Five experiments were done to establish the stability of PVY infectivity in sap. Sap was extracted from potato leaves infected with PVY isolate Del-3 (three experiments), or BL (two experiments) using a leaf press (Pollahne, Germany). The extracts were incubated and allowed to dry at room temperature for different time periods ( $5 \mathrm{~min}$ to $52 \mathrm{~h}$ ). For each time period, $2 \mathrm{ml}$ of sap extract containing isolate Del-3 or BL was placed into individual porcelain bowls. After each time period, 2 $\mathrm{ml}$ of distilled water was added to the infective sap to resuspend it. In each experiment, after each time period once the sap was resuspended, it was immediately inoculated without buffer or abrasive onto leaves of five to 10 tobacco plants ( 3 leaves/plant). Five to 10 tobacco plants were left uninoculated as controls. A single newly emerged leaf was sampled from each plant from 21 up to 40 days after inoculation and tested individually for PVY by ELISA.

Stability on surfaces. Three experiments were done to establish the stability of PVY infectivity on different surfaces. Sap was extracted from potato leaves infected with PVY isolate Del-3 using a leaf press and placed on each surface. The test surfaces were: cotton fabric (worn and washed), tire (inner rubber tube), metal (steel), hessian (worn), and wood (weathered stake). On each surface, $0.5 \mathrm{ml}$ of infective sap was applied to a $2 \times 2 \mathrm{~cm}$ area. For all experiments, the applied sap was left to dry at room temperature for $5 \mathrm{~min}, 3,6$, and $24 \mathrm{~h}$ after application. There were five replications of each surface for each time period. For each replication, the surface contaminated with infective sap was rubbed without buffer or abrasive directly onto the upper surface of leaves of a tobacco plant (3 leaves/plant). For controls, five plants were left uninoculated for each time period, and two plants were inoculated without buffer or abrasive with the fresh sap extract. A single newly emerged leaf was sampled from each plant from 21 up to 26 days after inoculation and tested individually for PVY by ELISA.

Inactivation. To investigate inactivation of PVY by disinfectants, sap was extracted from potato leaves infected with PVY isolate Del-3 using a leaf press. One milliliter of extract was diluted with $1 \mathrm{ml}$ of each of the following: nonfat dried milk (20\% wt/vol); Virkon-S powder (potassium peroxymonosulfate $50 \% \mathrm{wt} / \mathrm{wt}$, diluted to $1 \%$ ); household bleach (sodium hypochlorite $42 \mathrm{~g} /$ liter, $4 \%$ available chlorine, diluted 1:4); household disinfectant (benzalkonium chloride $1.5 \% \mathrm{wt} / \mathrm{wt}$, diluted 1:20); and distilled water. All disinfectants were used at the manufacturer's recommended rates, diluted in distilled water, and used immediately. The mixture of infective sap and disinfectant was left for $1 \mathrm{~min}$ prior to being rubbed onto leaves of tobacco plants without buffer or abrasive. Five plants (three leaves/plant), were used for each experimental treatment (disinfectants). For controls, five plants were rubbed with healthy sap diluted in distilled water (1:1) without buffer or abrasive. A single newly emerged leaf was sampled from each plant from 21 up to 34 days after inoculation and tested individually for PVY by ELISA.

Infection sources. Weeds and volunteer potatoes. In November 2012, leaf samples of weeds were collected from seven fields from three potato growing regions in southwest Australia (four fields at Pemberton, two at Myalup, and one at Manjimup). Each field had a history of PVY infection from seed potato crops grown in 2010 2012. For each weed species, leaf samples were tested in groups of two to 10 for PVY by ELISA, depending on the total number of leaves/species collected. The weed species tested were Arctotheca calendula (capeweed), Sonchus oleraceus (sowthistle), family Asteraceae; Raphanus raphanistrum (wild radish), family Brassicaceae; Chenopodium murale (fat hen), family Chenopodiaceae; Trifolium spp. (various clover species), and Vicia benghalensis (purple vetch), family Fabaceae; Watsonia bulbillifera, family Iridaceae; Mentha pulegium (pennyroyal), family Lamiaceae; Malva parviflora (mallow), family Malvaceae; Polygonum aviculare (wireweed), and Rumex spp. (dock), family Polygonaceae; and Datura spp. (thornapple), and S. nigrum (black nightshade), family Solanaceae. In addition, leaves from volunteer potatoes present at four sites (two fields each at Pemberton and Myalup) were sampled and tested by ELISA in groups of 10 for presence of PVY, PLRV, PVX, PVS, and TSWV.

Potato crops. Between September 2012 and April 2013, 4,740 leaf samples from ware (fresh and processing) potato crops were collected from 51 crops in five regions (Busselton, Dandaragan, Manjimup, Myalup, and Pemberton). These samples were tested by ELISA for PVY. In addition, results from PVY tests on 13,100 leaf samples from 155 seed potato crops from 34 cultivars submitted for virus testing to AgWest Plant Laboratories, Department of Agriculture and Food, Western Australia in July 2012 to June 2013 were collated. They had tested the leaf samples from each crop by ELISA for PVY in groups of 15.

Host reactions and seed transmission in S. nigrum. Plants of a range of (i) common indicator hosts (Chenopodium amaranticolor, C. quinoa, Gomphrena globosa, Nicotiana benthamiana, Nicotiana glutinosa, N. tabacum); (ii) potential alternative hosts (Capsicum annuиm cv. Lestat, S. nigrum, tomato cv. Grosse Lisse, and Vigna unguiculata); and (iii) potato cvs. Bliss and White Rose were grown in an insect-proofed glasshouse. For each host species, except $S$. nigrum, five plants each were sap inoculated with PVY isolates BL or Del-3. Five plants for each host species were left uninoculated as controls. For S. nigrum, 19 plants at the 3- to 4-leaf stage were inoculated with PVY isolate BL and nine plants with Del-3. Ten plants were left uninoculated as controls. After sap inoculation, symptoms in inoculated and newly emerged leaves were recorded weekly, and samples from inoculated and tip leaves from each plant were tested individually by ELISA for PVY infection from 21 up to 42 days after inoculation. Seed was collected from the PVY-infected $S$. nigrum plants, germinated, and when plants were at the 4-leaf stage, a leaf sample was collected from each plant, and these samples were tested for PVY in groups of 10 by ELISA. 


\section{Results}

Contact transmission. Leaf-to-leaf transmission. With each of seven experiments, regardless of the isolate used, half to all plants of each cultivar became infected after rubbing them with PVYinfected leaves (Table 1). Symptoms in infected plants were: leaf mottle and mild distortion with cvs. Bliss, White Rose, and Innovator; and systemic necrosis leading to leaf drop and plant death for cv. Atlantic. $\mathrm{Cv}$. White Star developed symptomless infection. None of the control plants ever became infected.

Tuber-to-leaf transmission. In the five experiments with isolate $\mathrm{BL}$, the number of plants that became infected after rubbing with the cut surface of an infected tuber ranged from 2-7/12 for cv. White Rose and 0-10/10 for cv. Bliss (Table 1). For PVY isolate Del-3, 2/8 plants of cv. White Rose became infected in the single experiment. All infected plants developed mild leaf mottle. None of the control plants ever became infected. All cut-infected tubers were confirmed as infected when grown out.

Leaf sap contaminated cutting blades to tubers. When healthy cv. White Rose tubers were cut with a PVY sap contaminated knife, transmission occurred at low levels, in one experiment each with isolates BL (2/15) and Del-3 (1/13), but no transmission occurred in the second experiment with either isolate (Table 2). When cv. Bliss tubers were cut, low level (1/22) transmission occurred in one of the two experiments with Del-3, but there was no transmission in the single experiment with isolate BL. No transmission occurred when cv. White Star tubers were cut. When data from all eight experiments were combined, the overall rate of infecting tubers was $2 \%$. Infected plants of both cultivars developed mild leaf mottle.

Tuber-to-tuber transmission. When each infected tuber was cut, very little sap stuck to the blade. When healthy tubers of cvs. Bliss or White Rose were cut using a blade previously used to cut an infected tuber, no transmission occurred with either isolate/cultivar combination from a total of 171 tuber pieces grown (Table 2). All cut-infected tubers were confirmed as infected when grown out.
Stability. Survival in dried sap. With isolate Del-3, sap from PVY-infected potato plants remained highly infective for up to 6 to $7 \mathrm{~h}$, with over half to all tobacco plants being infected. It remained infective for up to $28 \mathrm{~h}$, but only minimal infectivity was detected after $24 \mathrm{~h}$ and none after $28 \mathrm{~h}$ (Table 3). With isolate BL, sap from infected potato plants was highly infective for up to 6 to $7 \mathrm{~h}$ with $2 / 5$ to $9 / 10$ plants becoming infected, and minimal infectivity for up to $24 \mathrm{~h}$.

Stability on surfaces. In the three experiments on stability of PVY infectivity on different surfaces, when the sap was applied to hessian or wood it dried quickly (within $30 \mathrm{~min}$ ) and was absorbed into the surface, whereas with metal and tire it dried without being absorbed. PVY was infectious to tobacco plants for up to $6 \mathrm{~h}$ after extraction on all surfaces (Table 4). With tire and metal, limited infectivity remained for at least $24 \mathrm{~h}$, but with cotton, wood, and hessian it was no longer infective at $24 \mathrm{~h}$. With wood and hessian, PVY was highly infective at $5 \mathrm{~min}$, whereas at 3 to $6 \mathrm{~h}$ there was limited infectivity. With the controls, all plants became infected when inoculated with freshly extracted infective sap, but none became infected when healthy plants were left uninoculated.

Inactivation. In the three experiments, when disinfectant was added to sap from PVY-infected leaves prior to inoculation, no tobacco plants became infected with Virkon-S (1\%) or bleach (1:4) (Table 5). When nonfat dried milk was used, only one plant became infected across the three experiments. In contrast, all tobacco plants became infected in each experiment with household disinfectant, distilled water, or undiluted infective sap. None of the control plants became infected. When their appearance was compared with that of control plants, no phytotoxic damage to plants was caused by any of the inactivation treatments.

Infection sources. PVY was not detected in any of the 722 weed samples from 13 weed species belonging to six families tested (number of samples tested in parentheses): A. calendula (15), C. murale (48), Datura spp. (35), M. parviflora (56), $M$. pulegium (11), P. aviculare (26), S. nigrum (52), R. raphanistrum

Table 1. Contact transmission of Potato virus $Y\left(\mathrm{PVY}^{\circ}\right)$ to potato plants by rubbing with infected leaves or cut tubers

\begin{tabular}{|c|c|c|c|c|}
\hline Exp. & Rubbing treatment ${ }^{\mathrm{a}}$ & PVY isolate & Potato cultivar & Number of plants PVY-infected/total number of plants ${ }^{b}$ \\
\hline 1 & Leaf & BL & Atlantic & $5 / 10$ \\
\hline 2 & & & Bliss & $7 / 10$ \\
\hline 3 & & & White Rose & 9/9 \\
\hline 4 & & & White Star & $6 / 10$ \\
\hline 5 & & Del-3 & Bliss & $10 / 10$ \\
\hline 6 & & & Innovator & $9 / 9$ \\
\hline 7 & & & White Rose & $10 / 12$ \\
\hline $1-3$ & Tuber & BL & Bliss & $10 / 10$ \\
\hline $4-5$ & & & White Rose & $7 / 12$ \\
\hline 6 & & Del-3 & White Rose & $2 / 8$ \\
\hline
\end{tabular}

${ }^{\mathrm{a}}$ Leaf $=$ infected leaf gently rubbed onto healthy plant leaf; Tuber = infected tuber cut and surface rubbed onto healthy plant leaf.

${ }^{\mathrm{b}}$ A newly emerged leaf from each plant was tested individually up to 48 days after inoculation by ELISA. Five to six healthy potato plants of the same cultivar were rubbed with healthy leaves or tubers as controls, for each experiment but none became infected.

Table 2. Transmission of Potato virus $Y\left(\mathrm{PVY}^{\circ}\right)$ from contaminated cutting blades to potato tubers

\begin{tabular}{|c|c|c|c|c|}
\hline Exp. & $\begin{array}{l}\text { Blade contamination } \\
\text { treatment }^{\mathrm{a}}\end{array}$ & PVYo isolate $^{\circ}$ & Potato cultivar & $\begin{array}{l}\text { Number of plants PVY-infected/total number } \\
\text { of plants grown from cut tuber pieces }\end{array}$ \\
\hline 1 & Sap & BL & Bliss & $0 / 21$ \\
\hline 2,3 & & $\mathrm{BL}$ & White Rose & $0 / 20$ \\
\hline 4,5 & & Del-3 & Bliss & $0 / 40$ \\
\hline 6,7 & & Del-3 & White Rose & $0 / 19$ \\
\hline 8 & & Del-3 & White Star & $0 / 32$ \\
\hline 1 & Tuber & BL & Bliss & $0 / 69$ \\
\hline 2 & & $\mathrm{BL}$ & White Rose & $0 / 16$ \\
\hline 3 & & Del-3 & Bliss & $0 / 69$ \\
\hline 4 & & Del-3 & White Rose & $0 / 17$ \\
\hline
\end{tabular}

a Sap = knife blade dipped into PVY-infective sap before cutting through a healthy potato tuber. Tuber = scalpel blade used to cut PVY-infected tuber before cutting through a healthy potato tuber.

${ }^{b}$ The cut tuber was left at room temperature to heal for $24 \mathrm{~h}$, before each cut tuber piece were planted and allowed to sprout. A newly emerged leaf from each plant was tested individually up to 62 days after planting by ELISA. For each experiment (1-8), 10 healthy tubers of the same cultivar were cut with a blade dipped in healthy potato sap as controls, but none became infected. 
(129), Trifolium spp. (171), S. oleraceus (28), Rumex spp. (76), V. benghalensis (20), and W. bulbillifera (55). From a total of 190 volunteer potato plants tested from four sites, PVY (4\% incidence) and PVX (4\% incidence) were detected at one site near Pemberton. PVY had previously been detected in 2011 in a third generation seed potato crop at this site. PLRV was detected in volunteer potato samples from the three other sites (2 to $19 \%$ incidence). No PVS or TSWV was detected in any of the samples tested. From 4,740 leaf samples from ware potato crops, PVY was detected in 6 of 16 crops from one region (Pemberton) at incidences of 1 to $>10 \%$, but not in the 35 crops from the four other regions. Infected cultivars were Bliss (3 crops), Nadine (1 crop), Almera (1 crop), and FL1867 (1 crop). From a total of 13,100 leaf samples from 155 seed potato crops from 34 cultivars submitted to AgWest Plant Laboratories for virus testing between July 2012 and June 2013, PVY was detected on four occasions, in cvs. MacRusset (1), Bliss (1), and White Rose (2), at incidences of $<2 \%$.
Host reactions and seed transmission in $S$. nigrum. When inoculated with each of the two $\mathrm{PVY}^{\mathrm{O}}$ isolates, the symptom reactions in each host and potato cultivar were the same except for tomato, which developed symptomless infection with isolate BL, but remained uninfected with Del-3. With both isolates, infected plants of potato cvs. Bliss and White Rose developed mild leaf mottle and leaf distortion. Plants of $N$. benthamiana, $N$. glutinosa, and N. tabacum developed leaf mottle and leaf distortion. Plants of C. amaranticolor developed faint chlorotic spots on inoculated leaves, while $C$. quinoa had symptomless local infection; no systemic infection developed in either. Plants of C. annuum, G. globosa, and $V$. unguiculata did not become infected with either PVY isolate. A total $16 / 28$ plants of $S$. nigrum became infected systemically with isolates BL (8/19) and Del-3 (8/9) after sap inoculation, but no symptoms developed in them. When seeds from PVYinfected $S$. nigrum plants were grown out, no PVY was detected in any of the 2,640 plants tested.

Table 3. Infectivity of Potato virus $Y\left(\mathrm{PVY}^{\circ}\right)$ sap incubated for different time periods before inoculation to tobacco plants

\begin{tabular}{|c|c|c|c|c|c|c|c|c|c|c|}
\hline \multirow[b]{3}{*}{ Exp. no. } & \multirow[b]{3}{*}{ PVYo isolate } & \multicolumn{9}{|c|}{ Number of plants PVY-infected/total number inoculated ${ }^{a}$} \\
\hline & & \multicolumn{9}{|c|}{ Incubation time periods prior to inoculation ${ }^{b}$} \\
\hline & & $5 \mathrm{~min}$ & $3 \mathbf{h}$ & $5-6 h^{c}$ & $7 \mathrm{~h}$ & $24 \mathrm{~h}$ & $27 \mathrm{~h}$ & $28-30 h^{d}$ & $48 \mathrm{~h}$ & $52 \mathrm{~h}$ \\
\hline 1 & Del-3 & $8 / 8$ & $8 / 8$ & $8 / 8$ & $-\mathrm{e}$ & $8 / 8$ & - & - & - & - \\
\hline 2 & Del-3 & $7 / 7$ & - & $4 / 7$ & - & $0 / 7$ & $1 / 7$ & $0 / 7$ & $0 / 7$ & $0 / 7$ \\
\hline 3 & Del-3 & $10 / 10$ & - & $10 / 10$ & $10 / 10$ & $1 / 10$ & $0 / 10$ & $2 / 10$ & - & - \\
\hline 4 & BL & $10 / 10$ & - & $8 / 10$ & $9 / 10$ & $0 / 10$ & - & $0 / 10$ & - & - \\
\hline 5 & BL & $5 / 5$ & $3 / 5$ & $2 / 5$ & - & $1 / 5$ & $0 / 5$ & $0 / 5$ & - & - \\
\hline
\end{tabular}

${ }^{a}$ There were five experiments. Samples from newly emerged leaves from all plants were tested individually by ELISA up to 40 days after inoculation. In each experiment, for each time period the same numbers of tobacco plants were left uninoculated as controls, but none ever became infected.

${ }^{\mathrm{b}}$ Sap extracted from PVY-infected leaves was left at room temperature in porcelain bowls for the incubation period, then resuspended in distilled water (1:1) and inoculated immediately to plants.

${ }^{\mathrm{c}}$ Incubation time was $5 \mathrm{~h}$ for experiments 3 and 4 , and $6 \mathrm{~h}$ for experiments 1,2 , and 5 .

${ }^{\mathrm{d}}$ Incubation time was $28 \mathrm{~h}$ for experiments 3 and 4 , and $30 \mathrm{~h}$ for experiments 2 and 5.

e $-=$ not tested.

Table 4. Infectivity of Potato virus $Y\left(\mathrm{PVY}^{\circ}\right)$ in sap after incubation on five surfaces for different time periods before inoculation to tobacco plants

\begin{tabular}{|c|c|c|c|c|}
\hline \multirow[b]{3}{*}{ Surface } & \multicolumn{4}{|c|}{ Number of plants PVY infected ${ }^{a}$} \\
\hline & \multicolumn{4}{|c|}{ Incubation time periods prior to inoculation ${ }^{b}$} \\
\hline & $5 \mathrm{~min}$ & $3 \mathbf{h}$ & $6 \mathrm{~h}$ & $24 \mathrm{~h}$ \\
\hline Cotton & $5,5,5^{\mathrm{c}}$ & $5,5,5$ & $5,2,1$ & $0,0,0$ \\
\hline Hessian & $5,5,4$ & $1,0,0$ & $0,1,0$ & $0,0,0$ \\
\hline Tire - inner tube & $4,5,4$ & $4,3,1$ & $3,4,2$ & $1,0,0$ \\
\hline Wood & $4,4,5$ & $0,1,1$ & $0,0,1$ & $0,0,0$ \\
\hline Metal & $5,5,5$ & $5,1,3$ & $3,0,0$ & $1,0,0$ \\
\hline
\end{tabular}

a There were three experiments with each surface. Each treatment consisted of five plants of tobacco. Isolate Del-3 was used.

${ }^{\mathrm{b}}$ Sap extracted from PVY-infected leaves was applied to surface, left at room temperature for each incubation period and then wiped onto upper leaf surface of healthy plants.

${ }^{\mathrm{c}}$ Numbers of plants infected in first, second, and third experiments separated by commas. A newly emerged leaf from each plant was tested individually up to 32 days after inoculation by ELISA. For each experiment, for each time period five tobacco plants were left uninoculated as controls, but none became infected.

Table 5. Inactivation of Potato virus $Y$ (PVY) in infective sap by various disinfectants

\begin{tabular}{|c|c|c|c|}
\hline \multirow[b]{3}{*}{ Treatment (product, dilution, active ingredient) } & \multicolumn{3}{|c|}{ No. of plants PVY infected ${ }^{a}$} \\
\hline & \multicolumn{3}{|c|}{ Experiment } \\
\hline & 1 & 2 & 3 \\
\hline Bleach (1:4) (42g/liter sodium hypochlorite, $4 \%$ chlorine) & 0 & 0 & 0 \\
\hline Household disinfectant (1:20) (benzalkonium chloride $1.5 \% \mathrm{wt} / \mathrm{wt}$ ) & 5 & 5 & 5 \\
\hline Non-fat dry milk (20\% wt/vol) & 0 & 1 & 0 \\
\hline Virkon-S (1\% wt/vol) (potassium peroxymonosulfate $50 \% \mathrm{wt} / \mathrm{wt}$ ) & 0 & 0 & 0 \\
\hline Distilled water & 5 & 5 & 5 \\
\hline Healthy sap & 0 & 0 & 0 \\
\hline
\end{tabular}

a Sap was extracted from PVY-infected leaves and diluted (1:1) with treatment disinfectant, left for 1 min and then used to inoculate plants without buffer or abrasive. PVY isolate Del-3 was used. For each experiment, each treatment consisted of five plants of tobacco. Tip leaves from all plants were tested individually by ELISA up to 34 days after inoculation. For each experiment, for treatment five tobacco plants were left uninoculated as controls, but none became infected. 


\section{Discussion}

This study shows that PVY ${ }^{\mathrm{O}}$ can spread readily from infected to healthy potato plants by leaf-to-leaf contact, to a lesser extent by tuber-to-leaf contact, and to a very limited extent when blades contaminated with infective leaf sap are used to cut healthy potato tubers. There was no tuber-to-tuber transmission when blades were used to cut infected and then healthy tubers. These data provide important new information about the spread of $\mathrm{PVY}^{\mathrm{O}}$ in potato, as previously there was conflicting evidence over its contact transmissibility. Our findings provide evidence that $\mathrm{PVY}^{\mathrm{O}}$ is likely to be transmitted from infected to healthy potato plants through foliage contact both along and between rows after the canopy closes and when their foliage is damaged by equipment. It also provides evidence that PVY transmission occurs rarely when tubers are cut with blades contaminated with infective sap. We found a small amount of transmission occurred when a blade was contaminated with infective leaf sap, but none when tuber-to-tuber transmission was investigated. We also found that $\mathrm{PVY}^{\mathrm{O}}$ remained infective in sap kept at room temperature for up to $28 \mathrm{~h}$, and for up to $6 \mathrm{~h}$ after drying on cotton, hessian, and wood, and up to $24 \mathrm{~h}$ on tire and metal. Fortunately, $\mathrm{PVY}^{\mathrm{O}}$ was completely inactivated by household bleach and Virkon-S, and very little infectivity remained when nonfat dried milk was used, so this is also likely to be useful. Understanding that $\mathrm{PVY}^{\mathrm{O}}$ has the potential to spread through sap contamination on several common surfaces highlights the need to ensure that machinery, equipment, and clothing are cleaned before moving between crops. This research therefore highlights the importance of sanitation and hygiene practices in seed potato production.

We used the methodology of Coutts et al. (7), whereby all experiments on PVY stability in sap were done without any inoculation buffer or water during extraction or abrasive during plant inoculation (e.g., celite or Carborundum). This contrasts with other virus contact transmission studies in which these were included $(4,55)$. If their approach had been used in our experiments, the duration of PVY infectivity might have been longer. All our experiments were done using $\mathrm{PVY}^{\mathrm{O}}$, as this is the only strain group found so far in potato in Western Australia. Although PVY ${ }^{\mathrm{N}}$ has been associated with contact transmission in the past $(8,12)$, it was not used in this study due to quarantine restrictions over its importation to Western Australia. Although there seems no reason to expect different results with other PVY strain groups, it would be interesting to repeat this type of study with $\mathrm{PVY}^{\mathrm{N}}$, as previous reports of contact transmission were with this strain $(8,12)$. Other investigations have suggested that strains that are recombinants between $\mathrm{PVY}^{\mathrm{N}}$ and $\mathrm{PVY} \mathrm{Y}^{\mathrm{O}}$ may have increased fitness $(25,27,39)$, so it would also be worthwhile to include these in future work.

In our PVY leaf-to-leaf contact transmission experiments, no damage was visible following leaf rubbing. Potato leaf surfaces are covered with long, thick, sharp hairs, although their densities, lengths, and natures vary with cultivar $(19,37)$. The light rubbing of leaves done in these experiments was therefore sufficient to create minute scratches on the leaf surface which allowed PVY to enter cells and infect the potato plant. Contact transmission of PVY could occur when infected plants touch healthy ones within rows, or subsequently when they meet across rows when the canopy closes. Our series of experiments inoculating potato plants with the cut surfaces of PVY-infected tubers produced differing results. In some experiments, all potato plants became infected, whereas in one experiment no plants were infected. We always used tubers harvested from glasshouse grown $\mathrm{PVY}^{\mathrm{O}}$-infected plants that were symptomatic and had been tested previously for PVY by ELISA. The cut tubers were grown out following rubbing on leaves, and the plants produced were always found to be PVY-infected. However, the duration of storage of harvested tubers at $4^{\circ} \mathrm{C}$ prior to cutting varied between experiments. A likely explanation for these differing results is that PVY distribution within tubers varies with strain, cultivar, and time in storage $(13,46,51)$.

Many potato crops are grown from small, whole seed tubers as the intact skin forms an effective barrier against soilborne patho- gens in general and, by eliminating the cutting operation, there is also reduced spread of contact-transmitted viruses (e.g., PVX and PVS) and seed-borne bacterial pathogens. However, there are still many occasions where seed potato tubers are cut prior to planting due to factors like seed tuber cost and lack of seed availability. Therefore, seed cutters should always be cleaned and sanitized regularly to reduce the spread of viruses and other pathogens (3). Draper and Gudmestad (10) reported tuber-to-tuber transmission of PVY by cutting knives, but Sturz et al. (50) found no evidence of this with $\mathrm{PVY}$. Here, we dipped a cutting blade in undiluted $\mathrm{PVY}^{\mathrm{O}}$-infective sap, and $2 \%$ of cut tuber pieces became PVYinfected. Thus, when cutting blades were contaminated with a potent PVY inoculum, it was spread occasionally. In our experiments, no tuber-to-tuber spread occurred when $\mathrm{PVY}^{\mathrm{O}}$ infected tubers were cut before cutting healthy ones. We used a total of 100 tubers in these studies. However, further tubers would need to be cut to provide confidence that low rates of tuber-tuber transmission never occur. Thus, given the low transmission rates from tuber cutting by blades contaminated with infective leaf sap, and lack of tuber-to tuber spread found with 100 tubers, the possibility remains that $\mathrm{PVY}^{\mathrm{O}}$ might still spread occasionally when seed tubers are sliced by contaminated cutting tools.

We found PVY survived and was infective after drying on different common surfaces. Of particular interest was its survival for 24 $\mathrm{h}$ on vehicle tires and metal. Machinery and irrigation pivot wheels move through potato crops and so have the potential to spread PVY between plants readily. We investigated whether some commercially available disinfectants could inactivate PVY. We only used ones that satisfied the following criteria: previous evidence of virus inactivation, having short incubation times, being safe for users, being readily available, and of low cost. Although previously ineffective against ZYMV (7), household disinfectant (benzalkonium chloride) was included as a positive control along with distilled water. Virkon-S (1\%) and household bleach (sodium hypochlorite, diluted 1:4) completely prevented PVY infection. Although Virkon-S had not inactivated ZYMV successfully (7) when we used the same rate, it inactivated PVY in all three of our experiments. Previous studies found treating cutting tools contaminated with PVY (54), ZYMV (7), TMV (34), or HLFPV (26) with sodium hypochlorite eliminated virus transmission to tomato, zucchini, petunia, and hibiscus plants, respectively. When diluted, sodium hypochlorite has low toxicity, is easy to use, and is relatively low cost. However, a drawback is that its efficacy is reduced by organic matter and it is corrosive. A water rinse is necessary to reduce corrosion damage to metal surfaces (7). In addition, some studies found $20 \%$ nonfat dry milk prevented infection occurring from contaminated cutting tools. As a trace of infectivity remained when nonfat dry milk was used, it was not completely effective at removing all PVY infectivity in our study. However, because it is a low cost, low toxicity, easily disposed of treatment, it is still suitable for use in organic farming and can also be applied in seed potato production. As we only used $\mathrm{PVY}^{\mathrm{O}}$ in these experiments, evaluating the effectiveness of these disinfectants against other PVY strains would be appropriate to establish whether all respond similarly.

In fields in southwest Australia with a previous history of PVY ${ }^{\mathrm{O}}$ infection in potato, potential carry-over of the virus between potato crops was limited to volunteer potatoes ( $1 / 4$ fields), as no PVY was detected in any of the weed species present. Also, although $S$. nigrum became infected with $\mathrm{PVY}^{\mathrm{O}}$ in our glasshouse studies, no PVY seed transmission was found in it. With rotations of 3 to 5 years between seed potato crops, extensive grazing of regrowth in fields following seed potato production, sowing of various Trifolium spp. for pasture following harvest, and wide separation from ware potato crops, it seems likely that the principal means by which PVY enters seed potato crops in the region is from sowing infected seed tubers.

Integrated disease management (IDM) strategies for control of PVY in seed potato production were described previously $(3,9,15,18,25,33,41,45)$. The most important control measure is to 
always plant healthy seed tubers. Other recommended measures include: isolation of new early generation plantings from older ones and from ware crops; eliminating alternative hosts (weeds, volunteer potato); planting nonhost border crops around early generation seed crops; thorough visual inspections and timely rogueing of plants with obvious PVY symptoms; virus testing of leaf samples from early generation crops to detect symptomless PVY infection; use of mineral oils and straw mulch to suppress PVY spread by aphids; foliage destruction to avoid late PVY spread to tubers; and planting PVY resistant cultivars if available. However, potato growers may also be spreading PVY from infected to healthy potato plants inadvertently during their seed production activities including: moving machinery through crops (e.g., during spraying or fertilizing, on pivot wheels) and during crop monitoring (e.g., footwear or clothing). Many countries also have aphid monitoring systems that forecast timing of aphid flights. These can be used to help decisions of when to plant seed crops, spray with mineral oils, or destroy foliage late in the growing season. Measures that address contact transmission such as washing down machinery, disinfecting cutting tools and surfaces, and limiting handling and movement within crops are already in place to control PVX and PVS spread, and so will also help control PVY. Also, planting small uncut seed tubers is preferable to cutting large tubers for use as seed to avoid potential spread of diseases including PVS and PVX.

\section{Acknowledgments}

We thank Eva Gajda for assisting with ELISA testing of samples, Stuart Vincent for glasshouse support, and certified seed potato inspectors Dale Spencer, David Tooke, and Frank O'Donnell for sample collection. This research was funded by the Western Australian Agricultural Produce Committee-Potato Producers Committee.

\section{Literature Cited}

1. Bald, J. G., and Norris, D. O. 1945. Virus C from an old Australian variety of potato. Phytopathology 35:591-597.

2. Bald, J. G., and Pugsley, A. T. 1941. The main virus disease of the potato in Victoria. CSIRO pamphlet no. 110.

3. Banttari, E. E., Ellis, P. J., and Khurana, S. M. P. 1993. Management of diseases caused by viruses and viruslike pathogens. Pages 127-131 in: Potato Health Management. R. C. Rowe, ed. American Phytopathological Society, St. Paul, MN.

4. Broadbent, L., and Fletcher, J. T. 1963. The epidemiology of tomato mosaic IV. Persistence of virus on clothing and glasshouse structures. Ann. Appl. Biol. 52:233-241.

5. Burrows, M. E., and Zitter, T. A. 2005. Virus problems in potatoes. Cornell University. http://vegetablemdonline.ppath.cornell.edu/NewsArticles/Potato Virus.htm

6. Clark, M. F., and Adams, A. N. 1977. Characteristics of the microplate method of enzyme-linked immunosorbent assay for the detection of plant viruses. J. Gen. Virol. 34:475-483.

7. Coutts, B. A., Kehoe, M. A., and Jones, R. A. C. 2013. Zucchini yellow mosaic virus: Contact transmission, stability on surfaces, and inactivation with disinfectants. Plant Dis. 97:765-771.

8. De Bokx, J. A. 1987. Biological properties. Pages 58-79 in: Viruses of potatoes and seed-potato production. J. A. De Bokx and J. P. H. van der Want, eds. Pudoc, Wageningen, The Netherlands.

9. De Bokx, J. A., and van der Want, J. P. H. 1987. Viruses of potatoes and seed-potato production, 2nd ed. Pudoc, Wageningen, The Netherlands.

10. Draper, M. A., and Gudmestad, N. C. 1992. Mechanical transmission of PVY by seed cutting. Am. Potato J. 69:577-578.

11. Fallon, J. P., and de Hann, G. C. 1961. Potato variety trial. J. Agric. West. Aust. 4th Ser. 6:343-346.

12. Fletcher, J. D., Lewthwaite, S. L., Boddington, H. J., Nott, H. M., and Wood, R. J. 1996. Virus disease surveys of ware potato crops, Franklin County, North Island, New Zealand. N.Z. J. Crop Hortic. Sci. 24:7-12.

13. Fox, A., Evans, F., and Browning, I. 2005. Direct tuber testing for Potato $Y$ potyvirus by real-time RT-PCR and ELISA: Reliable options for post-harvest testing? EPPO Bull. 35:93-97.

14. Franc, G. D., and Bantarri, E. E. 2001. Transmission of viruses. Pages 159175 in: Viruses and virus-like diseases of potatoes and production of seedpotatoes. G. Loebenstein, P. H. Berger, A. A. Brunt, and R. H. Lawson, eds. Kluwer Academic Publishers, Dordrecht, The Netherlands.

15. Frost, K. E., Groves, R. L., and Charkowski, A. O. 2013. Integrated control of potato pathogens through seed potato certification and provision of clean seed potatoes. Plant Dis. 97:1268-1280.

16. Gibbs, A. J. 1977. Tobamovirus group. CMI/AAB Descriptions of Plant Viruses No. 184.
17. Gibson, R. W., Payne, R. W., and Katis, N. 1988. The transmission of potato virus $\mathrm{Y}$ by aphids of different vectoring abilities. Ann. Appl. Biol. 113:3543.

18. Gray, S., De Boer, S., Lorenzen, J., Karasev, A., Whitworth, J., Nolte, P., Singh, R., Boucher, A., and Xu, H. 2010. Potato virus $Y$ : An evolving concern for potato crops in the United States and Canada. Plant Dis. 94:13841397.

19. Gunenc, Y., and Gibson, R. W. 1980. Effects of glandular foliar hairs on the spread of potato virus Y. Potato Res. 23:345-351.

20. Hane, D. C., and Hamm, P. B. 1999. Effects of seedborne potato virus Y infection in two potato cultivars expressing mild disease symptoms. Plant Dis. 83:43-45.

21. Heath, R., Sward, R. J., Moran, J. R., Mason, A. J., and Hallam, N. D. 1987. Biological characterisation of six Australian isolates of Potato virus $Y$ and their serological detection by ELISA. Aust. J. Agric. Res. 38:395-402.

22. Holland, M. B., and Jones, R. A. C. 2005. Benefits of virus testing in seed schemes. Pages 81-87 in: Proceedings of 'Potato 2005' - Australian National Potato Conference. A. J. Pitt and C. Donald, eds. Cowes, Victoria, Australia.

23. Hu, J. S., Ferreira, S., Xu, M. Q., Lu, M., Iha, M., Pflum, E., and Wang, M. 1994. Transmission, movement and inactivation of cymbidium mosaic and odontoglossum ringspot viruses. Plant Dis. 78:633-636.

24. Jones, R. A. C. 1990. Strain group specific and virus specific hypersensitive reactions to infection with potyviruses in potato cultivars. Ann. Appl. Biol. 117:93-105.

25. Jones, R. A. C. 2014. Virus disease problems facing potato industries worldwide: Viruses found, climate change implications, rationalising virus strain nomenclature and addressing the Potato virus $Y$ issue. In: The Potato: Botany, Production and Uses. R. Navarre and M.J. Pavek, eds. CABI, Wallingford, UK.

26. Kamenova, I., and Adkins, S. 2004. Transmission, in planta distribution and management of Hibiscus latent Fort Pierce virus, a novel tobamovirus isolated from Florida hibiscus. Plant Dis. 88:674-679.

27. Karasev, A. V., and Gray, S. M. 2013. Continuous and emerging challenges of Potato virus $Y$ in potato. Annu. Rev. Phytopathol. 51:571-586.

28. Karasev, A. V., and Gray, S. M. 2013. Genetic diversity of Potato virus $Y$ complex. Am. J. Potato Res. 90:7-13.

29. Kehoe, M. A., and Jones, R. A. C. 2011. A proposal to help resolve the disagreement between naming of potato virus $\mathrm{Y}$ strain groups defined by resistance phenotypes and those defined by sequencing. Arch. Virol. $156: 2273-2278$

30. Kerlan, C. 2006. Potato virus Y. CMI/AAB Description of Plant Viruses, No. 414.

31. Kerlan, C., Tribodet, M., Glais, L., and Guillet, M. 1999. Variability of potato virus $Y$ in potato crops in France. J. Phytopathol. 147:643-651.

32. Kirchner, S. M., Hiltunen, L. H., Santala, J., Döring, T. F., Ketola, J., Kankaala, A., Virtanen, E., and Valkonen, J. P. T. 2014. Comparison of straw mulch, insecticides, mineral oil, and birch extract for control of transmission of Potato virus $Y$ in seed potato crops. Potato Res. Published online doi:10.1007/s11540-014-9254-4

33. Koenig, R. 1978. Potexvirus group. CMI/AAB Description of Plant Viruses No. 200.

34. Lewandowski, D. J., Hayes, A. J., and Adkins, S. 2010. Surprising results from a search for effective disinfectants for Tobacco mosaic virus-contaminated tools. Plant Dis. 94:542-550.

35. Lowe, G. N. 1924. Cultivation of the potato. Seed: Its selection and treatment. J. Agric. West. Aust. 2nd Ser. 1:529-530.

36. MacKenzie, T. D., Fageria, M. S., Nie, X., and Singh, M. 2014. Effects of crop management practices on current season spread of Potato virus $Y$. Plant Dis. 98:231-222.

37. McCauley, M. M., and Evert, R. F. 1988. Morphology and vasculature of the leaf of potato (Solanum tuberosum). Am. J. Bot. 75:377-390.

38. McKirdy, S. J., Jones, R. A. C., and Sivasithamparam, K. 1998. Determining the effectiveness of grazing and trampling by livestock in transmitting white clover mosaic and subterranean clover mottle viruses. Ann. Appl. Biol. 132:91-105

39. Mehle, N., Kovac, M., Petrovic, N., Novak, M., Baebler, S., Stres, H. C. Gruden, K., and Ravnikar, M. 2004. Spread of potato virus $\mathrm{Y}^{\mathrm{NTN}}$ in potato cultivars (Solanum tuberosum L.) with different levels of sensitivity. Physiol. Mol. Plant Pathol. 64:293-300.

40. Nie, X., Singh, M., Pelletier, Y., and McLaren, D. 2013. Recent advances on Potato virus $Y$ research in Canada. Am. J. Potato Res. 90:14-20.

41. Nolte, P., Alvarez, J. M., and Whitworth, J. L. 2009. Potato virus $Y$ management for the seed potato producer. University of Idaho CIS 1165 http://www.cals.uidaho.edu/edcomm/pdf/CIS/CIS1165.pdf

42. Nolte, P., Whitworth, J. L., Thornton, M. K., and McIntosh, C. S. 2004 Effect of seedborne Potato virus $Y$ on performance of Russet Burbank, Russet Norkotah, and Shepody potato. Plant Dis. 88:248-252.

43. O'Neill, T., and Spence, N. 2003. Pepino mosaic virus of tomato - new results on virus persistence and disinfection. Factsheet 20/03. Horticultura Development Council. UK. http://www.hdc.org.uk/publication/2003-pepinomosaic-virus-tomato-\%E2\%80\%93-new-results-virus-persistence-and-disin fection

44. Rodoni, B. 2005. Potato virus $Y$ - a re-emerging problem. Pages $81-87$ in: 
Proceedings of 'Potato 2005' - Australian National Potato Conference. A. J. Pitt and C. Donald, eds. Cowes, Victoria, Australia.

45. Schramm, S., Frost, K., Charkowski, A., Gray, S., Crockford, A., and Groves, R. L. 2011. Management of potato virus Y (PVY) in Wisconsin seed potato production. Cooperative Extension Publishing, Madison, WI. http://learningstore.uwex.edu/Management-of-Potato-Virus-Y-PVY-in-Wis consin-Seed-Potato-Production--P1503.aspx

46. Singh, M., Singh, R. P., Fageria, M. S., Nie, X., Coffin, R., and Hawkins, G. 2013. Optimization of a real-time RT-PCR assay and its comparison with ELISA, conventional RT-PCR and the grow-out test for large scale diagnosis of Potato virus $Y$ in dormant potato tubers. Am. J. Potato Res. 90:43-50.

47. Singh, R. P., Valkonen, J. P. T., Gray, S. M., Boonham, N., Jones, R. A. C., Kerlan, C., and Schubert, J. 2008. Discussion paper: The naming of Potato virus Y strains infecting potato. Arch. Virol. 153:1-13.

48. Slack, S. A. 1993. Seed certification and seed improvement programs. Pages 61-65 in: Potato Health Management. R. C. Rowe, ed. American Phytopathological Society, St. Paul, MN.

49. Stevenson, W. R., Loria, R., Franc, G. D., and Weingartner, D. P. 2001. Compendium of Potato Diseases, 2nd ed. American Phytopathological Society, St. Paul, MN.

50. Sturz, A. V., Stewart, J. G., McRae, K. B., Diamond, J. F., Lu, X., and
Singh, R. P. 2000. Assessment of the importance of seed cutting, in-season cultivation, and the passage of row equipment in the spread of $\mathrm{PVY}^{\mathrm{O}}$ in potatoes. Can. J. Plant Pathol. 22:166-173.

51. Whitworth, J. L., Hamm, P. B., and Nolte, P. 2012. Distribution of Potato virus $Y$ strains in tubers during the post-harvest period. Am. J. Potato Res. 89:136-141.

52. Whitworth, J. L., Nolte, P., McIntosh, C., and Davidson, R. 2006. Effect of Potato virus $\mathrm{Y}$ on yield of three potato cultivars grown under different nitrogen levels. Plant Dis. 90:73-76.

53. Wilson, C. R., and Jones, R. A. C. 1990. Virus content of seed potato stocks produced in a unique seed potato production scheme. Ann. Appl. Biol 116:103-109.

54. Wintermantel, W. M. 2011. A comparison of disinfectants to prevent spread of potyviruses in greenhouse tomato production. Plant Health Progress. Online publication doi: 10.1094/PHP-2011-0221-01-RS

55. Wright, N. S. 1974. Retention of infectious potato virus $X$ on common surfaces. Am. Potato J. 51:251-253.

56. Zheng, L., Schultz, L., Cogan, N., Milinkovic, M., Slater, A., Thomas, J., and Rodoni, B. 2012. Genome sequencing of Australian Potato virus Y isolates. (Abstr.) Page 67 in: Proceedings 10th Australas. Plant Virology Workshop, 19-22 November 2012, Hamner Springs, New Zealand. 